\title{
Alternative Pathway Dysregulation and the Conundrum of Complement Activation by IgG4 Immune Complexes in Membranous Nephropathy
}

\section{Dorin-Bogdan Borza*}

Department of Microbiology and Immunology, Meharry Medical College, Nashville, TN, USA

Membranous nephropathy ( $\mathrm{MN})$, a major cause of nephrotic syndrome, is a noninflammatory immune kidney disease mediated by IgG antibodies that form glomerular subepithelial immune complexes. In primary $\mathrm{MN}$, autoantibodies target proteins expressed on the podocyte surface, often phospholipase A2 receptor (PLA2R1). Pathology is driven by complement activation, leading to podocyte injury and proteinuria.

OPEN ACCESS

Edited by:

Anil Chauhan

Saint Louis University, USA

Reviewed by:

Kimberly Jean Reidy,

The Children's Hospital at Montefiore, USA; Albert Einstein College of Medicine, USA

Alfred Hyoungju Kim, Washington University School of Medicine, USA

*Correspondence:

Dorin-Bogdan Borza dborza@mmc.edu

Specialty section: This article was submitted to Alloimmunity and Transplantation,

a section of the journal

Frontiers in Immunology

Received: 17 February 2016 Accepted: 11 April 2016

Published: 25 April 2016

Citation:

Borza D-B (2016) Alternative Pathway Dysregulation and the Conundrum of

Complement Activation by lgG4 Immune Complexes in Membranous Nephropathy. Front. Immunol. 7:157. doi: 10.3389/fimmu.2016.00157
This article overviews the mechanisms of complement activation and regulation in $\mathrm{MN}$, addressing the paradox that anti-PLA2R1 and other antibodies causing primary MN are predominantly (but not exclusively) IgG4, an IgG subclass that does not fix complement. Besides immune complexes, alterations of the glomerular basement membrane (GBM) in MN may lead to impaired regulation of the alternative pathway (AP). The AP amplifies complement activation on surfaces insufficiently protected by complement regulatory proteins. Whereas podocytes are protected by cell-bound regulators, the GBM must recruit plasma factor $\mathrm{H}$, which inhibits the AP on host surfaces carrying certain polyanions, such as heparan sulfate (HS) chains. Because HS chains present in the normal GBM are lost in MN, we posit that the local complement regulation by factor $\mathrm{H}$ may be impaired as a result. Thus, the loss of GBM HS in MN creates a micro-environment that promotes local amplification of complement activation, which in turn may be initiated via the classical or lectin pathways by subsets of lgG in immune complexes. A detailed understanding of the mechanisms of complement activation and dysregulation in $\mathrm{MN}$ is important for designing more effective therapies.

Keywords: membranous nephropathy, IgG4, complement, alternative pathway, factor $\mathrm{H}$, heparan sulfate, glomerular basement membrane

\section{INTRODUCTION}

One of the major causes of idiopathic nephrotic syndrome in adults, membranous nephropathy $(\mathrm{MN})$ is an immune kidney disease is mediated by IgG antibodies that form glomerular subepithelial immune complexes (1). Histologic hallmarks of MN are granular capillary loop deposits containing antigen, IgG, and complement, an expansion of the glomerular basement membrane (GBM), subepithelial electron-dense deposits, and podocyte foot process effacement, but little glomerular 
inflammation. Clinically, MN presents as proteinuria and often nephrotic syndrome. The natural course of the disease is variable. While some patients spontaneously remit, up to $40 \%$ of $\mathrm{MN}$ patients progress to end-stage renal disease over a period of 5-10 years. Another one-third of MN patients have persistent nephrotic syndrome, often with secondary complications of hyperlipidemia and hypercoagulability (2).

The current paradigm for the pathogenesis of $\mathrm{MN}$ has emerged from studies of Heymann nephritis, a rat model closely recapitulating human $\mathrm{MN}$ (3). The central pathogenic events are the formation of subepithelial immune complexes, which activate complement, thereby causing complement-mediated podocytes injury and proteinuria. This article overviews the mechanisms of complement activation and regulation in MN. The author further posits that complement activation in $\mathrm{MN}$ is exacerbated by GBM alterations, which impair normal complement regulation.

\section{IMMUNE COMPLEXES, TARGET ANTIGENS, AND ANTIBODIES MEDIATING MN}

Membranous nephropathy has a heterogeneous etiology. About $25 \%$ of cases, classified as secondary $\mathrm{MN}$, are associated with autoimmune disease (most often lupus nephritis), infections, toxins, drugs, or malignancy. More common is primary (idiopathic) MN, now understood as an organ-specific autoimmune disease. Subepithelial immune complexes may form by several mechanisms (4). In secondary MN, immune complexes typically form when "planted antigens" extrinsic to the glomerulus become lodged in the subepithelial space and subsequently bind IgG antibodies. The target antigens are not always known. An example is cationic bovine serum albumin (presumably of dietary origin) in pediatric $\mathrm{MN}$ (5).

Relevant to primary $\mathrm{MN}$, in the paradigm established in rat Heymann nephritis models, an intrinsic antigen located on the podocyte cell surface binds antibodies, forming in situ immune complexes, which are shed subepithelially. In rats, megalin is the major target of antibodies induced by immunization with crude Fx1A antigen (6). In human disease, the first podocyte antigen identified is neutral endopeptidase (NEP), targeted in rare forms of alloimmune $\mathrm{MN}(7,8)$. NEP-deficient mothers who are alloimmunized during a previous miscarriage produce anti-NEP alloantibodies that cross the placenta and bind to NEP in the fetal kidneys, causing antenatal MN.

Primary $\mathrm{MN}$ is mediated by IgG autoantibodies targeting proteins on the podocyte cell surface. Phospholipase A2 receptor (PLA2R1), a glycoprotein from the mannose receptor family, is targeted by autoantibodies in $\sim 70 \%$ of patients with primary $\mathrm{MN}$ (9). Another $3-5 \%$ of patients with primary $\mathrm{MN}$ have autoantibodies targeting thrombospondin type-1 domaincontaining 7A (THSD7A), another podocytes glycoprotein (10). Additional autoantibodies to proteins expressed intracellularly by podocytes (aldose reductase, manganese superoxide dismutase, and alpha-enolase), possibly generated after the initial injury by inter-molecular epitope spreading, are variably present in $\mathrm{MN}$ $(11,12)$; their pathogenic significance remains uncertain.
How antibodies causing MN mediate glomerular injury is incompletely understood. Human IgG comprises four subclasses with different effector ability (13). Most often in primary MN (but rarely in secondary MN), IgG4 is the major subclass of antibodies forming subepithelial immune complexes. IgG4 antibodies are non-inflammatory because they undergo dynamic Fab arm exchange, swapping half-molecules to form bispecific, functionally monovalent IgG4 (14). Relevant to the focus of this article, IgG4 does not activate complement (15). This poses the conundrum of how complement is activated in primary MN.

\section{COMPLEMENT ACTIVATION IN MN}

The complement system is a component of the innate immunity, which provides host defense against pathogens and is also important for the clearance of immune complexes and damaged cells and for immunoregulation (16). However, excessive complement activation or insufficient regulation causes tissue injury in many autoimmune or inflammatory diseases (17). Kidney glomerulus is particularly sensitive to complement-mediated injury (18).

\section{Overview of the Complement Cascade and Effector Mechanisms}

Activation of the complement cascade is initiated by three pathways (classical, lectin, and alternative) converging toward the generation of $\mathrm{C} 3$ convertases, which cleave $\mathrm{C} 3$ into $\mathrm{C} 3 \mathrm{a}$ and $\mathrm{C} 3 \mathrm{~b}$. Addition of $\mathrm{C} 3 \mathrm{~b}$ to $\mathrm{C} 3$ convertases generates $\mathrm{C} 5$ convertases, which cleave $\mathrm{C} 5$ into $\mathrm{C} 5 \mathrm{a}$ and $\mathrm{C} 5 \mathrm{~b}$, activating the terminal complement pathway. C5b sequentially binds C6, C7, C8 and C9, forming C5b-9. Effector molecules produced by complement activation include anaphylatoxins (C3a, C5a) that recruit and activate inflammatory cells, opsonins $(\mathrm{C} 3 \mathrm{~b}, \mathrm{iC} 3 \mathrm{~b})$ that bind to target surfaces and promote phagocytosis, and the membrane attack complex (C5b-9), which lyses cells.

Complement activation plays a key role in the pathogenesis of MN $(3,19,20)$. In human and experimental MN, C3 and C5b-9 commonly accompany IgG in subepithelial deposits $(21,22)$. C3d, a stable product of C3b breakdown, is found in glomerular deposits of all $\mathrm{MN}$ patients, while $\mathrm{C} 3 \mathrm{c}$ staining (detecting $\mathrm{C} 3 \mathrm{~b} /$ $\mathrm{iC} 3 \mathrm{~b}$ ) may be absent in patients with less proteinuria (23), possibly reflecting inactive disease. In this regard, glomerular $\mathrm{C} 3 \mathrm{c}$ staining indicates ongoing complement activation while $\mathrm{C} 3 \mathrm{~d}$ is a marker of past complement activation (24). The urinary excretion of $\mathrm{C} 3 \mathrm{dg}$ and C5b-9 correlates with disease activity in primary $\mathrm{MN}$ (25-27). In Heymann nephritis, proteinuria can be prevented by the depletion of C3 and also of C6 $(28,29)$, the latter implicating podocyte injury by C5b-9 as a major effector mechanism, as first shown in perfused rat glomeruli (30). Sublethal injury by C5b-9 triggers maladaptive changes in podocytes that disrupt the glomerular filtration barrier and cause proteinuria, reviewed in detail elsewhere (31-33).

\section{Classical Pathway}

The classical pathway is initiated when $\mathrm{Clq}$ binds to immune complexes containing IgM or certain IgG subclasses. Consequent activation of $\mathrm{C} 1 \mathrm{r}$ and $\mathrm{C} 1$ s cleaves $\mathrm{C} 4$, eventually forming $\mathrm{C} 4 \mathrm{~b} 2 \mathrm{~b}$, 
the C3 convertase of the classical and lectin pathways (LPs). Among human IgG subclasses, IgG3 and IgG1 strongly bind $\mathrm{C} 1 \mathrm{q}$ and activate complement, while IgG4 does not (13). In antenatal alloimmune MN, complement-fixing IgG1 anti-NEP alloantibodies are associated with severe proteinuria, whereas IgG4 anti-NEP cause limited disease (34). Likewise, in active and passive Heymann nephritis, only complement-fixing subclasses (sheep $\gamma 1$, rat IgG2b) induce proteinuria $(28,35)$.

Paradoxically, in primary MN, subepithelial immune complexes contain predominantly (but not exclusively) IgG4 (36), which neither binds C1q nor activates complement. C1q staining in primary $\mathrm{MN}$ is absent (37) or weak, as detected using more sensitive staining (21). In patient sera, quantitative immunoassays of anti-PLA2R subclasses also show a prevalence of IgG4, which on average comprises $\sim 50 \%$ of anti-PLA2R IgG (38). Smaller proportions of IgG1 ( 9\%) and IgG3 ( $6 \%)$ are also found, which may be sufficient to activate the classical pathway, albeit inefficiently.

The role of IgG4 antibodies in $\mathrm{MN}$ - whether they are protective or pathogenic - remains a conundrum. In 5-10\% of patients seropositive for anti-PLA2R1, IgG4 autoantibodies are negative (39). A unique case of recurrent MN features monoclonal IgG3kappa anti-PLA2R1, associated with glomerular C1q deposition (40). Therefore, IgG4 antibodies are not absolutely required for primary MN. Interestingly, IgG1 is prevalent in the earlier stages of primary $\mathrm{MN}$, as in secondary $\mathrm{MN}$, while IgG4 staining (inversely correlated with $\mathrm{C1q}$ ) prevails at later stages of primary MN (41). This suggests that IgG autoantibodies undergo a subclass switch from IgG1 to IgG4 during disease progression, as a temporal model of IgG function proposes (42). If so, the classical pathway may be more important in early MN, while other pathways become dominant as disease progresses (43).

\section{Lectin Pathway}

The LP is initiated when mannan-binding lectin (MBL) or ficolins bind to patterns of carbohydrates present on pathogens or damaged self, activating MBL-associated serine proteases to produce C2b4b. MBL binds to "G0" glycoforms of IgG that lack terminal sialic and galactose residues on the conserved $\mathrm{N}$-glycan in the Fc region, activating the LP (44). IgG-G0 glycoforms comprise $\sim 25 \%$ of all IgG in normal human sera, but are increased in some autoimmune diseases (45). Glomerular deposition of MBL occurs in some MN patients $(21,46)$, suggestive of the LP activation. This is consistent with preliminary studies reporting that affinitypurified anti-PLA2R1 IgG4 autoantibodies bind MBL, promoting C4 deposition (47). Further studies extending these investigations to other IgG subclasses and other pathways are needed to clarify the contribution of the LP to overall complement activation by anti-PLA2R1 autoantibodies.

\section{Alternative Pathway}

The alternative pathway (AP) is constitutively active at low levels. Slow spontaneous hydrolysis of the thioester bond of C3 ("tickover") generates $\mathrm{C} 3\left(\mathrm{H}_{2} \mathrm{O}\right)$, which in the presence of factors $\mathrm{B}$ and $\mathrm{D}$ produces $\mathrm{C} 3\left(\mathrm{H}_{2} \mathrm{O}\right) \mathrm{Bb}$, the initial $\mathrm{C} 3$ convertase of the AP. This cleaves $\mathrm{C} 3$ to $\mathrm{C} 3 \mathrm{~b}$, unmasking the reactive thioester, which allows $\mathrm{C} 3 \mathrm{~b}$ to attach covalently to surfaces. Unless inactivated by complement regulatory proteins (next section), surface-bound $\mathrm{C} 3 \mathrm{~b}$ binds factor $\mathrm{B}$, allowing cleavage by factor $\mathrm{D}$ to form $\mathrm{C} 3 \mathrm{bBb}$, the major $\mathrm{C} 3$ convertase of the AP. $\mathrm{C} 3 \mathrm{bBb}$ cleaves additional $\mathrm{C} 3$ molecules, generating more surface-bound C3b (Figure 1A). Through this positive feedback loop, the AP amplifies complement activation, even when $\mathrm{C} 3 \mathrm{~b}$ is initially produced by other pathways (48). Amplification is limited by the intrinsic instability of C3bBb, which decays when $\mathrm{Bb}$ dissociates irreversibly. Properdin stabilizes surface-bound $\mathrm{C} 3 \mathrm{bBb}$, significantly extending its half-life (49). In addition, properdin tethered to surface-bound C3b or tissue glycosaminoglycans may direct $\mathrm{AP}$ activation by providing a platform for $\mathrm{C} 3 \mathrm{bBb}$ convertase assembly (50-52).

Glomerular deposition of factor B found in MN biopsies provides circumstantial evidence that the AP is activated in disease (21). Moreover, MN was reported in a patient with C4 deficiency (53), in which the classical and LPs are not functional. In preliminary studies, we evaluated the role of the AP in experimental $\mathrm{MN}$ in mice. Mice immunized with $\alpha 3$ (IV) collagen NC1 domain develop subepithelial immune complexes and proteinuria,

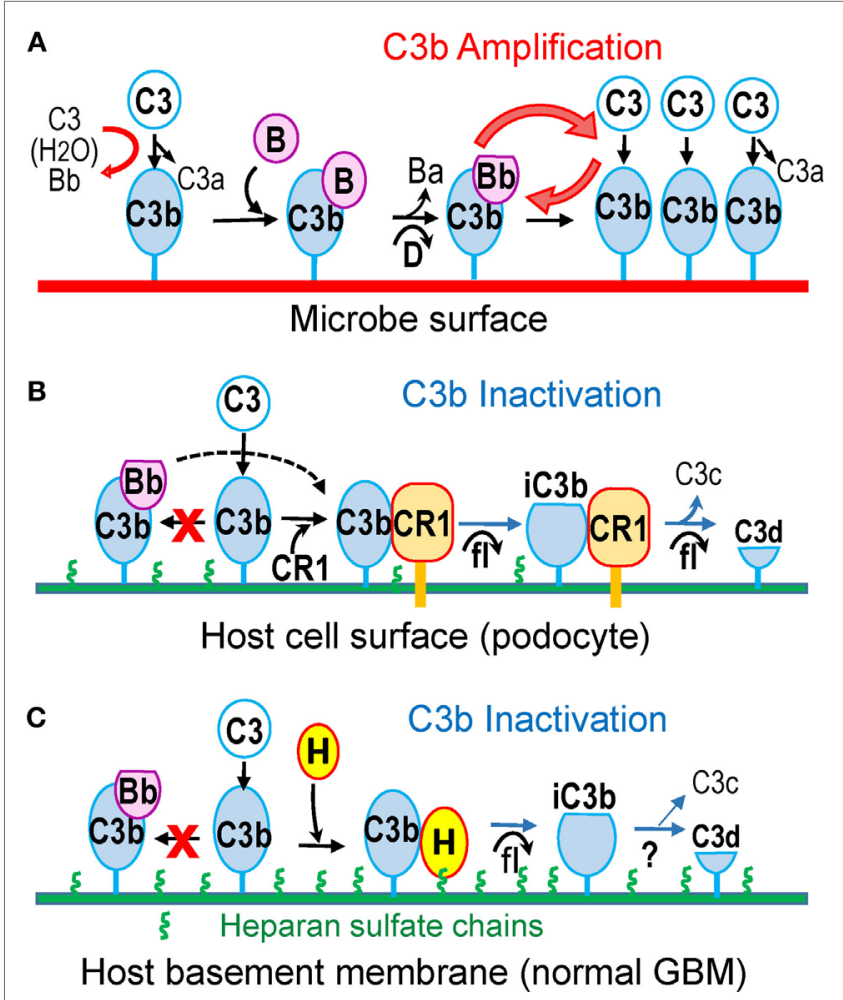

FIGURE 1 | Alternative pathway amplifies complement activation on pathogen surfaces but not on host surfaces protected by complement regulatory proteins (CRP). (A) C3b is continuously generated in fluid phase due to tick-over. C3b deposited on complementactivating surfaces (such as microbes) binds factor $\mathrm{B}$, which is cleaved by factor $\mathrm{D}$ to form the $\mathrm{C} 3 \mathrm{bBb}$ convertase, thus amplifying C3b generation. (B) On the surface of host cells, such as podocytes, membrane-bound CRPs (illustrated by CR1) catalyze factor I-mediated proteolytic inactivation of C3b to iC3b and C3d. CR1 also accelerates the decay of C3bBb convertase, if present (dotted line). (C) The extracellular matrix, such as the normal GBM, contains heparan sulfate chains (green), which recruit factor $\mathrm{H}$ from plasma to inactivate surface-bound C3b in a manner similar to cell-bound CRPs. 
recapitulating clinical and morphologic hallmarks of $\mathrm{MN}$ $(54,55)$. In factor $\mathrm{B}^{-/-}$mice, without a functional AP, glomerular $\mathrm{C} 3 \mathrm{c}$ and $\mathrm{C} 5 \mathrm{~b}-9$ deposition and proteinuria were prevented, while circulating and kidney-bound IgG were unchanged (56). These findings imply that the AP is required for complement activation and proteinuria in experimental MN.

\section{COMPLEMENT REGULATION IN MN}

Activation of complement, and in particular that of the AP, must be closely regulated to avoid damage to the host. This is achieved by cell-associated and fluid-phase complement regulatory proteins (CRP).

\section{Cell-Bound Complement Regulators}

Glomerular cells express several membrane-bound CRPs, which inactivate the $\mathrm{C} 3 / \mathrm{C} 5$ convertases of all pathways in the immediate proximity of cell surfaces (20). These include decay-accelerating factor (DAF, CD55), which inhibits complement activation by accelerating the dissociation of all convertases, membrane cofactor protein (MCP, CD46), which catalyzes the proteolytic inactivation of $\mathrm{C} 3 \mathrm{~b} / \mathrm{C} 4 \mathrm{~b}$ by factor I, and complement receptor 1 (CR1, CD35), which has both decay-accelerating and cofactor activity (Figure 1B). In addition, cells are protected by membrane-bound CD59, which inhibits the formation of C5b-9.

Studies of experimental MN demonstrate the protective role of membrane-bound CRPs. In active Heymann nephritis, complement activation and proteinuria are dependent on the formation of function-blocking antibodies to Crry (the rodent equivalent of human CR1) and CD59, which are present in crude preparations of Fx1A antigen used to induce disease (57). Anti-Fx1A antibodies used to induce passive Heymann nephritis also contain anti-Crry and anti-CD59 antibodies, which in vitro inhibit complement regulation on rat podocytes, allowing complement activation via the $\operatorname{AP}(58,59)$. Although autoantibodies to podocyte CRPs have not been described in human MN, staining for CR1 on podocytes is decreased in MN and other glomerular diseases (60). An acquired loss of CR1 may increase podocyte susceptibility to complement-mediated attack.

\section{Fluid Phase Complement Regulators: Factor $\mathrm{H}$}

The major regulator of the AP in the fluid phase is factor $\mathrm{H}$, an abundant plasma glycoprotein is composed of 20 domains named short consensus repeats (SCRs). Factor $\mathrm{H}$ inhibits the $\mathrm{AP}$ by accelerating the decay of the $\mathrm{C} 3 \mathrm{bBb}$ convertase and by catalyzing proteolytic inactivation of $\mathrm{C} 3 \mathrm{~b}$ to $\mathrm{iC} 3 \mathrm{~b}$ by factor I (61, 62). These complement regulatory activities are mediated by the amino-terminal SCR1-4 of factor H (63), which are necessary and sufficient to inhibit the AP in the fluid phase.

Factor $\mathrm{H}$ also inhibits the AP on host surfaces carrying certain polyanions as markers of self. Factor $\mathrm{H}$ has two distinct heparin-/glycosaminoglycan-binding sites, located in the SCR7 and SCR19-20 (64), which recognize heparan sulfate (HS) chains in a tissue-specific manner (65). In addition, SCR20 binds specific sialic acid structures (66). Recognition of these host-specific polyanions enables factor $\mathrm{H}$ to discriminate between self and pathogen surfaces. Surface polyanions increase the affinity of factor $\mathrm{H}$ for surface-bound $\mathrm{C} 3 \mathrm{~b}$, exposing its complement regulatory domains to inactivate C3b (67-69). Consequently, host surfaces coated by HS (or sialic acid) are complement non-activators because they recruit factor $\mathrm{H}$ effectively to inhibit the AP (70-72). In contrast, surfaces lacking these polyanions do not bind factor $\mathrm{H}$, allowing complement activation and amplification. Impaired attachment of factor $\mathrm{H}$ to polyanions on glomerular endothelial cells, as a result of mutations or inhibitory autoantibodies, causes atypical hemolytic uremic syndrome, even though AP regulation in plasma is normal (73-76).

\section{Loss of Glomerular Heparan Sulfate in MN May Impair Local AP Regulation}

Lacking protection from cell-bound CRPs (in contrast to podocytes), the GBM must recruit plasma factor $\mathrm{H}$ for local AP regulation. Putative ligands are HS chains attached to agrin core protein, which are particularly abundant in the normal GBM (77). Indeed, factor $\mathrm{H}$ (as well as its carboxyl-terminal domains SCR19-20) binds to glomeruli in a manner that can be inhibited by heparin, suggesting interactions with glycosaminoglycans (78). In functional assays, HS from the eye Bruch's membrane inhibits the AP (79). Similarly, glomerular HS proteoglycans may recruit factor $\mathrm{H}$ to locally inhibit the AP in the GBM (Figure 1C).

A striking loss of HS chains from the GBM (detected by staining with mAb JM403) occurs in human MN, while staining for agrin core protein is unaltered (80). The loss of GBM HS, correlated with complement deposition and albuminuria, is recapitulated in active and passive Heymann nephritis $(81,82)$. The underlying mechanism may be an upregulation of heparanase in glomeruli (83). Heparanase, a beta-D-endoglycosidase, is the only mammalian enzyme that degrades HS chains. Rarely expressed in normal tissues, heparanase is upregulated in various pathologic conditions (84). An upregulation of glomerular heparanase occurs in Heymann nephritis, which is prevented by C3 depletion (85). Increased glomerular staining and urinary excretion of heparanase occurs in human $\mathrm{MN}(86)$.

We postulate that in $\mathrm{MN}$, the acquired loss of glomerular HS chains would impair the ability of factor $\mathrm{H}$ to inactivate $\mathrm{C} 3 \mathrm{~b}$ deposited within the GBM (Figure 2A). Thus, alterations of the GBM composition in MN may lead to the local dysregulation of the AP. Similar to pathogen surfaces, the altered GBM would allow amplification of complement activation, which in turn may be initiated via the classical (or lectin) pathway by subsets of IgG1/IgG3 (or IgG-G0) in immune complexes. By itself, the loss of GBM HS appears insufficient to trigger sustained glomerular complement activation in the absence of glomerular immune complexes; for instance, glomerular $\mathrm{C} 3 \mathrm{c}$ is absent in diabetic nephropathy despite the loss of GBM HS chains. Therefore, subepithelial immune complexes and the local AP dysregulation may both contribute to complement activation in $\mathrm{MN}$, synergistically and by distinct mechanisms. 


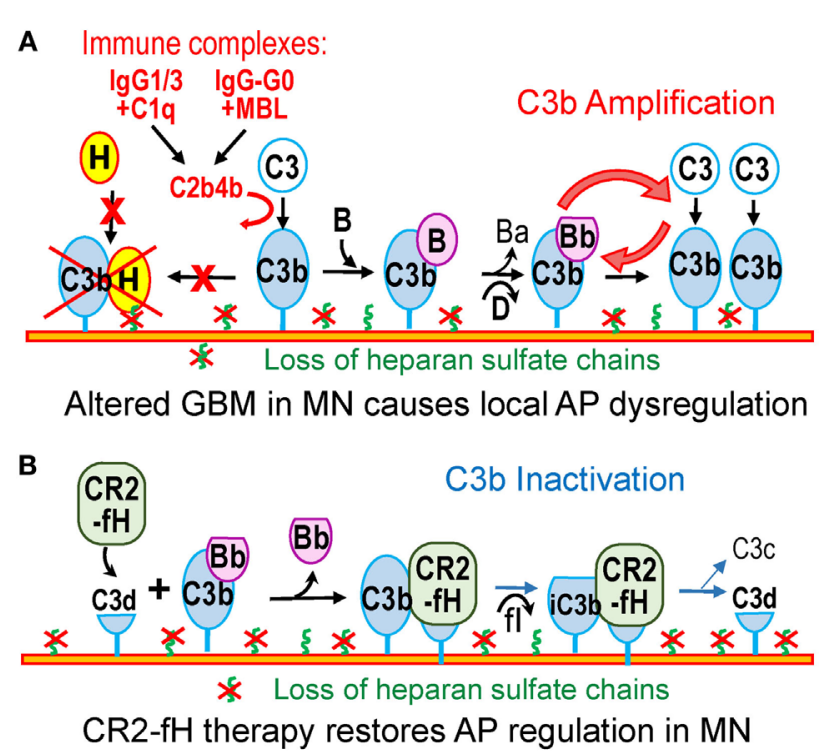

FIGURE 2 | Dysregulation of the alternative pathway in MN. (A) In MN, subsets of IgG1/3 or IgG-G0 in subepithelial immune complexes may activate the classical or lectin pathway. C3b thus generated attaches to nearby targets in the GBM or on podocytes. The loss of heparan sulfate in the GBM in MN impairs recruitment of factor $\mathrm{H}$ and inactivation of $\mathrm{C} 3 \mathrm{~b}$. As a result, the altered GBM resembles a pathogen surface that promotes C3b amplification. (B) Therapy with $\mathrm{CR} 2-\mathrm{fH}$ fusion protein overcomes the effects of the AP dysregulation in MN. CR2-fH is targeted at sites of complement activation in the GBM where iC3b or $\mathrm{C} 3 \mathrm{~d}$ are present, thus restoring the local inhibition of the AP.

\section{CONCLUDING REMARKS: COMPLEMENT AS A THERAPEUTIC TARGET IN MN}

More specific and effective therapies for treating $\mathrm{MN}$ remain a significant unmet need (87). Current therapies for MN rely on non-specific immunosuppression with cytotoxic agents or calcineurin inhibitors (along with low dose steroids), which have toxic side effects and are sometimes ineffective (88). A more specific intervention, the depletion of $B$ cells by rituximab (an anti-CD20 monoclonal antibody) has yielded promising results in small studies, though not all patients respond (89-91). Even when immuno-suppressive therapies work, pathogenic antibodies persist for many months and cause additional injury. Clinical improvement is further delayed as the reduction of proteinuria lags behind immunological remission (disappearance of antibodies) by several months $(92,93)$. Complement inhibition may prevent further glomerular damage until pathogenic antibodies disappear.

There are few clinical studies of complement inhibitors in MN. Eculizumab is a humanized $\operatorname{IgG} 2 / \operatorname{IgG} 4 \mathrm{mAb}$ that inhibits

\section{REFERENCES}

1. Beck LH Jr, Salant DJ. Membranous nephropathy: from models to man. J Clin Invest (2014) 124(6):2307-14. doi:10.1172/JCI72270

2. Nickolas TL, Radhakrishnan J, Appel GB. Hyperlipidemia and thrombotic complications in patients with membranous nephropathy. Semin Nephrol (2003) 23(4):406-11. doi:10.1016/S0270-9295(03)00058-5 terminal complement activation by binding to $\mathrm{C} 5$ and preventing its cleavage. A randomized trial of eculizumab in $\mathrm{MN}$ did not show significant reduction in proteinuria after 16 weeks (94), perhaps because of an insufficient dosage regimen (20). Of note, blocking complement at the level of C5 does not affect the upstream $\mathrm{C} 3$ convertases. It is therefore possible that excessive glomerular C3 deposition may also interfere with the glomerular filtration function, independent of C5b-9 formation. In $\mathrm{Cfh}^{-/-}$ mice (a model of $\mathrm{C} 3$ glomerulopathy, a kidney disease caused by the AP dysregulation), the ablation of C5 improves survival and reduces glomerular inflammation (mediated by $\mathrm{C} 5 \mathrm{a}$ ), but does not reduce proteinuria or glomerular C3 staining (95).

Therapeutic inhibition of the AP has the potential to limit amplification of complement activation, which may be beneficial in MN. Supporting this concept are our preliminary studies showing that the genetic ablation of factor B in mice uncouples subepithelial immune complexes from glomerular C3 deposition and proteinuria in experimental MN (56). Effective agents for systemic inhibition of the AP in vivo include anti-factor B monoclonal antibodies and anti-sense oligonucleotides $(96,97)$.

Another attractive strategy would be to correct specifically the local dysregulation of the AP, which can be achieved by using complement inhibitors targeted to sites of complement activation (98). The poster child for this approach is CR2-fH, a fusion protein comprising a fragment of complement receptor 2 (CR2) that recognizes $\mathrm{C} 3 \mathrm{~b}$ breakdown products (iC3b, C3dg, and C3d), linked to the complement inhibitory domains of factor $\mathrm{H}$ (99). CR2-fH reduces complement-mediated kidney injury in mouse models lupus nephritis and C3 glomerulopathy $(100,101)$. Because C3b breakdown fragments are deposited in the glomeruli in $\mathrm{MN}, \mathrm{CR} 2-\mathrm{fH}$ can bind at these sites to inhibit the AP even in the absence of HS chains (Figure 2B). In summary, a detailed understanding of the mechanisms of complement activation and dysregulation in $\mathrm{MN}$ is necessary to inform the design of safer, more effective, and specific therapies.

\section{AUTHOR CONTRIBUTIONS}

$\mathrm{D}-\mathrm{BB}$ developed the concepts, wrote the initial draft, revised the article, and approved the final version for publication.

\section{FUNDING}

$\mathrm{D}-\mathrm{BB}$ gratefully acknowledges funding provided through the Norman S. Coplon Extramural Grant Program by Satellite Healthcare, a not-for-profit renal care provider, and support by funds from the Meharry Medical College and the Meharry Translational Research Center grant U54 MD007593 from the National Institute on Minority Health and Health Disparities of the National Institutes of Health.

3. GlassockRJ. The pathogenesis ofidiopathic membranous nephropathy:a 50-year odyssey. Am J Kidney Dis (2010) 56(1):157-67. doi:10.1053/j.ajkd.2010.01.008

4. Nangaku M, Couser WG. Mechanisms of immune-deposit formation and the mediation of immune renal injury. Clin Exp Nephrol (2005) 9(3):183-91. doi:10.1007/s10157-005-0357-8

5. Debiec H, Lefeu F, Kemper MJ, Niaudet P, Deschenes G, Remuzzi G, et al. Early-childhood membranous nephropathy due to cationic bovine 
serum albumin. $N$ Engl J Med (2011) 364(22):2101-10. doi:10.1056/ NEJMoa1013792

6. Farquhar MG, Saito A, Kerjaschki D, Orlando RA. The Heymann nephritis antigenic complex: megalin (gp330) and RAP. JAm Soc Nephrol (1995) 6(1):35-47.

7. Debiec H, Guigonis V, Mougenot B, Decobert F, Haymann JP, Bensman A, et al. Antenatal membranous glomerulonephritis due to anti-neutral endopeptidase antibodies. N Engl J Med (2002) 346(26):2053-60. doi:10.1056/ NEJMoa012895

8. Debiec H, Nauta J, Coulet F, van der Burg M, Guigonis V, Schurmans T, et al. Role of truncating mutations in MME gene in fetomaternal alloimmunisation and antenatal glomerulopathies. Lancet (2004) 364(9441):1252-9. doi:10.1016/S0140-6736(04)17142-0

9. Beck LH Jr, Bonegio RG, Lambeau G, Beck DM, Powell DW, Cummins TD, et al. M-type phospholipase A2 receptor as target antigen in idiopathic membranous nephropathy. N Engl J Med (2009) 361(1):11-21. doi:10.1056/ NEJMoa0810457

10. Tomas NM, Beck LH Jr, Meyer-Schwesinger C, Seitz-Polski B, Ma H, Zahner G, et al. Thrombospondin type-1 domain-containing 7A in idiopathic membranous nephropathy. N Engl J Med (2014) 371(24):2277-87. doi:10.1056/NEJMoa1409354

11. Prunotto M, Carnevali ML, Candiano G, Murtas C, Bruschi M, Corradini E, et al. Autoimmunity in membranous nephropathy targets aldose reductase and SOD2. J Am Soc Nephrol (2010) 21(3):507-19. doi:10.1681/ASN.2008121259

12. Murtas C, Bruschi M, Candiano G, Moroni G, Magistroni R, Magnano A, et al. Coexistence of different circulating anti-podocyte antibodies in membranous nephropathy. Clin J Am Soc Nephrol (2012) 7(9):1394-400. doi:10.2215/CJN.02170312

13. Vidarsson G, Dekkers G, Rispens T. IgG subclasses and allotypes: from structure to effector functions. Front Immunol (2014) 5:520. doi:10.3389/ fimmu.2014.00520

14. van der Neut Kolfschoten M, Schuurman J, Losen M, Bleeker WK, Martinez - Martinez P, Vermeulen E, et al. Anti-inflammatory activity of human IgG4 antibodies by dynamic Fab arm exchange. Science (2007) 317(5844):1554-7. doi:10.1126/science.1144603

15. van der Zee JS, van Swieten P, Aalberse RC. Inhibition of complement activation by IgG4 antibodies. Clin Exp Immunol (1986) 64(2):415-22.

16. Ricklin D, Hajishengallis G, Yang K, Lambris JD. Complement: a key system for immune surveillance and homeostasis. Nat Immunol (2010) 11(9):785-97. doi:10.1038/ni.1923

17. Markiewski MM, Lambris JD. The role of complement in inflammatory diseases from behind the scenes into the spotlight. Am J Pathol (2007) 171(3):715-27. doi:10.2353/ajpath.2007.070166

18. Thurman JM. Complement in kidney disease: core curriculum 2015. Am J Kidney Dis (2015) 65(1):156-68. doi:10.1053/j.ajkd.2014.06.035

19. Cybulsky AV, Quigg RJ, Salant DJ. Experimental membranous nephropathy redux. Am J Physiol Renal Physiol (2005) 289(4):F660-71. doi:10.1152/ ajprenal.00437.2004

20. Cunningham PN, Quigg RJ. Contrasting roles of complement activation and its regulation in membranous nephropathy. J Am Soc Nephrol (2005) 16(5):1214-22. doi:10.1681/ASN.2005010096

21. Segawa $Y$, Hisano S, Matsushita M, Fujita T, Hirose S, Takeshita M, et al. IgG subclasses and complement pathway in segmental and global membranous nephropathy. Pediatr Nephrol (2010) 25(6):1091-9. doi:10.1007/ s00467-009-1439-8

22. Endo M, Fuke Y, Tamano M, Hidaka M, Ohsawa I, Fujita T, et al. Glomerular deposition and urinary excretion of complement factor $\mathrm{H}$ in idiopathic membranous nephropathy. Nephron Clin Pract (2004) 97(4):c147-53. doi: $10.1159 / 000079174$

23. Doi T, Kanatsu K, Nagai H, Suehiro F, Kuwahara T, Hamashima Y. Demonstration of C3d deposits in membranous nephropathy. Nephron (1984) 37(4):232-5. doi:10.1159/000183255

24. Schulze M, Pruchno CJ, Burns M, Baker PJ, Johnson RJ, Couser WG. Glomerular C3c localization indicates ongoing immune deposit formation and complement activation in experimental glomerulonephritis. Am J Pathol (1993) 142(1):179-87.

25. Brenchley PE, Coupes B, Short CD, O’Donoghue DJ, Ballardie FW, Mallick NP. Urinary C3dg and C5b-9 indicate active immune disease in human membranous nephropathy. Kidney Int (1992) 41(4):933-7. doi:10.1038/ ki. 1992.143

26. Kon SP, Coupes B, Short CD, Solomon LR, Raftery MJ, Mallick NP, et al. Urinary C5b-9 excretion and clinical course in idiopathic human membranous nephropathy. Kidney Int (1995) 48(6):1953-8. doi:10.1038/ki.1995.496

27. Coupes BM, Kon SP, Brenchley PE, Short CD, Mallick NP. The temporal relationship between urinary C5b-9 and C3dg and clinical parameters in human membranous nephropathy. Nephrol Dial Transplant (1993) 8(5):397-401.

28. Salant DJ, Belok S, Madaio MP, Couser WG. A new role for complement in experimental membranous nephropathy in rats. JClin Invest (1980) 66(6):1339-50. doi:10.1172/JCI109987

29. Baker PJ, Ochi RF, Schulze M, Johnson RJ, Campbell C, Couser WG. Depletion of C6 prevents development of proteinuria in experimental membranous nephropathy in rats. Am J Pathol (1989) 135(1):185-94.

30. Cybulsky AV, Rennke HG, Feintzeig ID, Salant DJ. Complement-induced glomerular epithelial cell injury. Role of the membrane attack complex in rat membranous nephropathy. J Clin Invest (1986) 77(4):1096-107. doi:10.1172/ JCI112408

31. Nangaku M, Shankland SJ, Couser WG. Cellular response to injury in membranous nephropathy. J Am Soc Nephrol (2005) 16(5):1195-204. doi:10.1681/ ASN.2004121098

32. Couser WG. Pathogenesis of glomerular damage in glomerulonephritis. Nephrol Dial Transplant (1998) 13(Suppl 1):10-5. doi:10.1093/ndt/13. suppl_1.10

33. Ronco P, Debiec H. Molecular pathomechanisms of membranous nephropathy: from Heymann nephritis to alloimmunization. J Am Soc Nephrol (2005) 16(5):1205-13. doi:10.1681/ASN.2004121080

34. Vivarelli M, Emma F, Pelle T, Gerken C, Pedicelli S, Diomedi - Camassei F, et al. Genetic homogeneity but IgG subclass-dependent clinical variability of alloimmune membranous nephropathy with anti-neutral endopeptidase antibodies. Kidney Int (2015) 87(3):602-9. doi:10.1038/ ki.2014.381

35. Noble B, Van Liew JB, Andres GA, Brentjens JR. Factors influencing susceptibility of LEW rats to Heymann nephritis. Clin Immunol Immunopathol (1984) 30(2):241-54. doi:10.1016/0090-1229(84)90059-X

36. Doi T, Mayumi M, Kanatsu K, Suehiro F, Hamashima Y. Distribution of IgG subclasses in membranous nephropathy. Clin Exp Immunol (1984) 58(1):57-62.

37. Jennette JC, Hipp CG. Immunohistopathologic evaluation of C1q in 800 renal biopsy specimens. Am J Clin Pathol (1985) 83(4):415-20. doi:10.1093/ ajcp/83.4.415

38. Kanigicherla D, Gummadova J, McKenzie EA, Roberts SA, Harris S, Nikam M, et al. Anti-PLA2R antibodies measured by ELISA predict long-term outcome in a prevalent population of patients with idiopathic membranous nephropathy. Kidney Int (2013) 83(5):940-8. doi:10.1038/ki.2012.486

39. Hofstra JM, Debiec H, Short CD, Pelle T, Kleta R, Mathieson PW, et al. Antiphospholipase A2 receptor antibody titer and subclass in idiopathic membranous nephropathy. JAm Soc Nephrol (2012) 23(10):1735-43. doi:10.1681/ASN.2012030242

40. Debiec H, Hanoy M, Francois A, Guerrot D, Ferlicot S, Johanet C, et al. Recurrent membranous nephropathy in an allograft caused by IgG3kappa targeting the PLA2 receptor. JAm Soc Nephrol (2012) 23(12):1949-54. doi:10.1681/ASN.2012060577

41. Huang CC, Lehman A, Albawardi A, Satoskar A, Brodsky S, Nadasdy G, et al. IgG subclass staining in renal biopsies with membranous glomerulonephritis indicates subclass switch during disease progression. Mod Pathol (2013) 26(6):799-805. doi:10.1038/modpathol.2012.237

42. Collins AM, Jackson KJA. Temporal model of human IgE and IgG antibody function. Front Immunol (2013) 4:235. doi:10.3389/fimmu.2013.00235

43. Ma H, Sandor DG, Beck LH Jr. The role of complement in membranous nephropathy. Semin Nephrol (2013) 33(6):531-42. doi:10.1016/j. semnephrol.2013.08.004

44. Malhotra R, Wormald MR, Rudd PM, Fischer PB, Dwek RA, Sim RB. Glycosylation changes of IgG associated with rheumatoid arthritis can activate complement via the mannose-binding protein. Nat Med (1995) 1(3):237-43. doi:10.1038/nm0395-237

45. Maverakis E, Kim K, Shimoda M, Gershwin ME, Patel F, Wilken R, et al. Glycans in the immune system and The Altered Glycan Theory of 
Autoimmunity: a critical review. J Autoimmun (2015) 57:1-13. doi:10.1016/j. jaut.2014.12.002

46. Lhotta K, Wurzner R, Konig P. Glomerular deposition of mannose-binding lectin in human glomerulonephritis. Nephrol Dial Transplant (1999) 14(4):881-6. doi:10.1093/ndt/14.4.881

47. Ma H, Beck LH Jr, Salant DJ. Membranous nephropathy-associated anti-phospholipase A2 receptor IgG4 autoantibodies activate the lectin complement pathway (abstract). J Am Soc Nephrol (2011) 22:62A.

48. Harboe M, Ulvund G, Vien L, Fung M, Mollnes TE. The quantitative role of alternative pathway amplification in classical pathway induced terminal complement activation. Clin Exp Immunol (2004) 138(3):439-46. doi:10.1111/j.1365-2249.2004.02627.x

49. Hourcade DE. The role of properdin in the assembly of the alternative pathway C3 convertases of complement. J Biol Chem (2006) 281(4):2128-32. doi:10.1074/jbc.M508928200

50. Spitzer D, Mitchell LM, Atkinson JP, Hourcade DE. Properdin can initiate complement activation by binding specific target surfaces and providing a platform for de novo convertase assembly. J Immunol (2007) 179(4):2600-8. doi:10.4049/jimmunol.179.4.2600

51. Zaferani A, Vives RR, van der Pol P, Hakvoort JJ, Navis GJ, van Goor H, et al. Identification of tubular heparan sulfate as a docking platform for the alternative complement component properdin in proteinuric renal disease. JBiol Chem (2011) 286(7):5359-67. doi:10.1074/ jbc.M110.167825

52. Lesher AM, Nilsson B, Song WC. Properdin in complement activation and tissue injury. Mol Immunol (2013) 56(3):191-8. doi:10.1016/j. molimm.2013.06.002

53. Lhotta K, Wurzner R, Rumpelt HJ, Eder P, Mayer G. Membranous nephropathy in a patient with hereditary complete complement C4 deficiency. Nephrol Dial Transplant (2004) 19(4):990-3. doi:10.1093/ndt/gfh008

54. Olaru F, Luo W, Suleiman H, St John PL, Ge L, Mezo AR, et al. Neonatal fc receptor promotes immune complex-mediated glomerular disease. J Am Soc Nephrol (2014) 25(5):918-25. doi:10.1681/ASN.2013050498

55. Zhang JJ, Malekpour M, Luo W, Ge L, Olaru F, Wang XP, et al. Murine membranous nephropathy: immunization with alpha3(IV) collagen fragment induces subepithelial immune complexes and FcgammaR-independent nephrotic syndrome. J Immunol (2012) 188(7):3268-77. doi:10.4049/ jimmunol.1103368

56. Luo W, Olaru F, Ge L, Rops AL, Van der Vlag J, Holers VM, et al. Alternative complement pathway is essential for glomerular $\mathrm{C} 3$ deposition and progressive proteinuria in murine membranous nephropathy [Abstract FR-OR140]. J Am Soc Nephrol (2012) 23:62A.

57. Schiller B, He C, Salant DJ, Lim A, Alexander JJ, Quigg RJ. Inhibition of complement regulation is key to the pathogenesis of active Heymann nephritis. J Exp Med (1998) 188(7):1353-8. doi:10.1084/jem.188.7.1353

58. Quigg RJ, Cybulsky AV, Salant DJ. Effect of nephritogenic antibody on complement regulation in cultured rat glomerular epithelial cells. J Immunol (1991) 147(3):838-45.

59. Quigg RJ, Holers VM, Morgan BP, Sneed AE III. Crry and CD59 regulate complement in rat glomerular epithelial cells and are inhibited by the nephritogenic antibody of passive Heymann nephritis. JImmunol (1995) 154(7):3437-43.

60. Moll S, Miot S, Sadallah S, Gudat F, Mihatsch MJ, Schifferli JA. No complement receptor 1 stumps on podocytes in human glomerulopathies. Kidney Int (2001) 59(1):160-8. doi:10.1046/j.1523-1755.2001.00476.x

61. Jozsi M, Zipfel PF. Factor H family proteins and human diseases. Trends Immunol (2008) 29(8):380-7. doi:10.1016/j.it.2008.04.008

62. Rodriguez de Cordoba S, Esparza-Gordillo J, Goicoechea de Jorge E, Lopez-Trascasa M, Sanchez-Corral P. The human complement factor H: functional roles, genetic variations and disease associations. Mol Immunol (2004) 41(4):355-67. doi:10.1016/j.molimm.2004.02.005

63. Gordon DL, Kaufman RM, Blackmore TK, Kwong J, Lublin DM. Identification of complement regulatory domains in human factor H. J Immunol (1995) 155(1):348-56.

64. Schmidt CQ, Herbert AP, Kavanagh D, Gandy C, Fenton CJ, Blaum BS, et al. A new map of glycosaminoglycan and C3b binding sites on factor $\mathrm{H}$. J Immunol (2008) 181(4):2610-9. doi:10.4049/jimmunol.181.4.2610

65. Langford-Smith A, Keenan TD, Clark SJ, Bishop PN, Day AJ. The role of complement in age-related macular degeneration: heparan sulphate, a
ZIP code for complement factor H? J Innate Immun (2014) 6(4):407-16. doi:10.1159/000356513

66. Blaum BS, Hannan JP, Herbert AP, Kavanagh D, Uhrin D, Stehle T. Structural basis for sialic acid-mediated self-recognition by complement factor $\mathrm{H}$. Nat Chem Biol (2015) 11(1):77-82. doi:10.1038/nchembio.1696

67. Pangburn MK. Host recognition and target differentiation by factor $\mathrm{H}$, a regulator of the alternative pathway of complement. Immunopharmacology (2000) 49(1-2):149-57. doi:10.1016/S0162-3109(00)80160-5

68. Meri S, Pangburn MK. Discrimination between activators and nonactivators of the alternative pathway of complement: regulation via a sialic acid/polyanion binding site on factor H. Proc Natl Acad Sci U S A (1990) 87(10):3982-6. doi:10.1073/pnas.87.10.3982

69. Kajander T, Lehtinen MJ, Hyvarinen S, Bhattacharjee A, Leung E, Isenman $\mathrm{DE}$, et al. Dual interaction of factor $\mathrm{H}$ with $\mathrm{C} 3 \mathrm{~d}$ and glycosaminoglycans in host-nonhost discrimination by complement. Proc Natl Acad Sci US A (2011) 108(7):2897-902. doi:10.1073/pnas.1017087108

70. Jozsi M, Oppermann M, Lambris JD, Zipfel PF. The C-terminus of complement factor H is essential for host cell protection. Mol Immunol (2007) 44(10):2697-706. doi:10.1016/j.molimm.2006.12.001

71. Jozsi M, Manuelian T, Heinen S, Oppermann M, Zipfel PF. Attachment of the soluble complement regulator factor $\mathrm{H}$ to cell and tissue surfaces: relevance for pathology. Histol Histopathol (2004) 19(1):251-8.

72. Ferreira VP, Herbert AP, Hocking HG, Barlow PN, Pangburn MK. Critical role of the $\mathrm{C}$-terminal domains of factor $\mathrm{H}$ in regulating complement activation at cell surfaces. J Immunol (2006) 177(9):6308-16. doi:10.4049/ jimmunol.177.9.6308

73. Jozsi M, Heinen S, Hartmann A, Ostrowicz CW, Halbich S, Richter H, et al. Factor $\mathrm{H}$ and atypical hemolytic uremic syndrome: mutations in the C-terminus cause structural changes and defective recognition functions. J Am Soc Nephrol (2006) 17(1):170-7. doi:10.1681/ASN.2005080868

74. Manuelian T, Hellwage J, Meri S, Caprioli J, Noris M, Heinen S, et al. Mutations in factor $\mathrm{H}$ reduce binding affinity to $\mathrm{C} 3 \mathrm{~b}$ and heparin and surface attachment to endothelial cells in hemolytic uremic syndrome. J Clin Invest (2003) 111(8):1181-90. doi:10.1172/JCI16651

75. Dragon-Durey MA, Loirat C, Cloarec S, Macher MA, Blouin J, Nivet H, et al. Anti-Factor $\mathrm{H}$ autoantibodies associated with atypical hemolytic uremic syndrome. JAm Soc Nephrol (2005) 16(2):555-63. doi:10.1681/ ASN.2004050380

76. Jozsi M, Strobel S, Dahse HM, Liu WS, Hoyer PF, Oppermann M, et al. Anti factor $\mathrm{H}$ autoantibodies block C-terminal recognition function of factor $\mathrm{H}$ in hemolytic uremic syndrome. Blood (2007) 110(5):1516-8. doi:10.1182/ blood-2007-02-071472

77. Raats CJ, Bakker MA, Hoch W, Tamboer WP, Groffen AJ, van den Heuvel LP, et al. Differential expression of agrin in renal basement membranes as revealed by domain-specific antibodies. J Biol Chem (1998) 273(28):17832-8. doi:10.1074/jbc.273.28.17832

78. Clark SJ, Ridge LA, Herbert AP, Hakobyan S, Mulloy B, Lennon R, et al. Tissue-specific host recognition by complement factor $\mathrm{H}$ is mediated by differential activities of its glycosaminoglycan-binding regions. J Immunol (2013) 190(5):2049-57. doi:10.4049/jimmunol.1201751

79. Kelly U, Yu L, Kumar P, Ding JD, Jiang H, Hageman GS, et al. Heparan sulfate, including that in Bruch's membrane, inhibits the complement alternative pathway: implications for age-related macular degeneration. J Immunol (2010) 185(9):5486-94. doi:10.4049/jimmunol.0903596

80. van den Born J, van den Heuvel LP, Bakker MA, Veerkamp JH, Assmann KJ, Weening JJ, et al. Distribution of GBM heparan sulfate proteoglycan core protein and side chains in human glomerular diseases. Kidney Int (1993) 43(2):454-63. doi:10.1038/ki.1993.67

81. Raats CJ, Luca ME, Bakker MA, Van Der Wal A, Heeringa P, Van Goor H, et al. Reduction in glomerular heparan sulfate correlates with complement deposition and albuminuria in active Heymann nephritis. J Am Soc Nephrol (1999) 10(8):1689-99.

82. Levidiotis V, Freeman C, Punler M, Martinello P, Creese B, Ferro V, et al. A synthetic heparanase inhibitor reduces proteinuria in passive Heymann nephritis. JAm Soc Nephrol (2004) 15(11):2882-92. doi:10.1097/01. ASN.0000142426.55612.6D

83. van den Hoven MJ, Rops AL, Vlodavsky I, Levidiotis V, Berden JH, van der Vlag J. Heparanase in glomerular diseases. Kidney Int (2007) 72(5):543-8. doi:10.1038/sj.ki.5002337 
84. Vlodavsky I, Friedmann Y, Elkin M, Aingorn H, Atzmon R, Ishai-Michaeli R, et al. Mammalian heparanase: gene cloning, expression and function in tumor progression and metastasis. Nat Med (1999) 5(7):793-802. doi:10.1038/10518

85. Levidiotis V, Freeman C, Tikellis C, Cooper ME, Power DA. Heparanase is involved in the pathogenesis of proteinuria as a result of glomerulonephritis. JAm Soc Nephrol (2004) 15(1):68-78. doi:10.1097/01. ASN.0000103229.25389.40

86. Rops AL, van den Hoven MJ, Veldman BA, Salemink S, Vervoort G, Elving LD, et al. Urinary heparanase activity in patients with Type 1 and Type 2 diabetes. Nephrol Dial Transplant (2012) 27(7):2853-61. doi:10.1093/ ndt/gfr732

87. Wiggins RC, Alpers CE, Holzman LB, He JC, Salant DJ, Chugh SS, et al. Glomerular disease: looking beyond pathology. Clin J Am Soc Nephrol (2014) 9(6):1138-40. doi:10.2215/CJN.01450214

88. Chen Y, Schieppati A, Cai G, Chen X, Zamora J, Giuliano GA, et al. Immunosuppression for membranous nephropathy: a systematic review and meta-analysis of 36 clinical trials. Clin J Am Soc Nephrol (2013) 8(5):787-96. doi:10.2215/CJN.07570712

89. Beck LH Jr, Fervenza FC, Beck DM, Bonegio RG, Malik FA, Erickson SB, et al. Rituximab-induced depletion of anti-PLA2R autoantibodies predicts response in membranous nephropathy. J Am Soc Nephrol (2011) 22(8):154350. doi:10.1681/ASN.2010111125

90. Bomback AS, Derebail VK, McGregor JG, Kshirsagar AV, Falk RJ, Nachman PH. Rituximab therapy for membranous nephropathy: a systematic review. Clin J Am Soc Nephrol (2009) 4(4):734-44. doi:10.2215/CJN.05231008

91. Fervenza FC, Abraham RS, Erickson SB, Irazabal MV, Eirin A, Specks U, et al. Rituximab therapy in idiopathic membranous nephropathy: a 2-year study. Clin J Am Soc Nephrol (2010) 5(12):2188-98. doi:10.2215/CJN.05080610

92. Fervenza FC, Sethi S, Specks U. Idiopathic membranous nephropathy: diagnosis and treatment. Clin J Am Soc Nephrol (2008) 3(3):905-19. doi:10.2215/ CJN.04321007

93. Waldman M, Austin HA III. Treatment of idiopathic membranous nephropathy. J Am Soc Nephrol (2012) 23(10):1617-30. doi:10.1681/ASN.2012010058

94. Appel G, Nachman P, Hogas S, Radhakrishnan J, Old C, Hebert L, et al. Eculizumab (C5a complement inhibitor) in the treatment of idiopathic membranous nephropathy [abstract]. J Am Soc Nephrol (2002) 13:668A.

95. Pickering MC, Warren J, Rose KL, Carlucci F, Wang Y, Walport MJ, et al. Prevention of C5 activation ameliorates spontaneous and experimental glomerulonephritis in factor H-deficient mice. Proc Natl Acad Sci U S A (2006) 103(25):9649-54. doi:10.1073/pnas.0601094103

96. Thurman JM, Kraus DM, Girardi G, Hourcade D, Kang HJ, Royer PA, et al. A novel inhibitor of the alternative complement pathway prevents antiphospholipid antibody-induced pregnancy loss in mice. Mol Immunol (2005) 42(1):87-97. doi:10.1016/j.molimm.2004.07.043

97. Grossman TR, Hettrick LA, Johnson RB, Hung G, Peralta R, Watt A, et al. Inhibition of the alternative complement pathway by antisense oligonucleotides targeting complement factor B improves lupus nephritis in mice. Immunobiology (2015). doi:10.1016/j.imbio.2015.08.001

98. Holers VM, Rohrer B, Tomlinson S. CR2-mediated targeting of complement inhibitors: bench-to-bedside using a novel strategy for sitespecific complement modulation. Adv Exp Med Biol (2013) 735:137-54. doi:10.1007/978-1-4614-4118-2_9

99. Huang Y, Qiao F, Atkinson C, Holers VM, Tomlinson S. A novel targeted inhibitor of the alternative pathway of complement and its therapeutic application in ischemia/reperfusion injury. J Immunol (2008) 181(11):8068-76. doi:10.4049/jimmunol.181.11.8068

100. Sekine H, Kinser TT, Qiao F, Martinez E, Paulling E, Ruiz P, et al. The benefit of targeted and selective inhibition of the alternative complement pathway for modulating autoimmunity and renal disease in MRL/lpr mice. Arthritis Rheum (2011) 63(4):1076-85. doi:10.1002/art.30222

101. Ruseva MM, Peng T, Lasaro MA, Bouchard K, Liu-Chen S, Sun F, et al. Efficacy of targeted complement inhibition in experimental C3 glomerulopathy. JAm Soc Nephrol (2016) 27(2):405-16. doi:10.1681/ ASN.2014121195

Conflict of Interest Statement: The author declares that the research was conducted in the absence of any commercial or financial relationships that could be construed as a potential conflict of interest.

Copyright (C) 2016 Borza. This is an open-access article distributed under the terms of the Creative Commons Attribution License (CC BY). The use, distribution or reproduction in other forums is permitted, provided the original author(s) or licensor are credited and that the original publication in this journal is cited, in accordance with accepted academic practice. No use, distribution or reproduction is permitted which does not comply with these terms. 